\title{
Pengaruh Media Tanam dan Jenis Tanaman Terhadap Produksi Nutrien Bagian Aerial Tanaman Sorgum dan Jagung
}

\author{
B. D. Cahyono, Sudiyono, E. Handayanta \\ Program Studi Peternakan, Fakultas Pertanian, Universitas Sebelas Maret
}

\begin{abstract}
ABSTRAK
Penelitian ini bertujuan untuk mengetahui pemanfaatan sludge biogas pada media tanam dengan melihat perbedaan produksi tanaman sorgum dan jagung. Penelitian ini dilaksanakan pada bulan November 2015 sampai dengan Februari 2016 di lahan sekitar perkandangan peternakan sapi potong Izzah Sejahtera Farm, Desa Jagoan, Kecamatan Sambi, Kabupaten Boyolali. Materi yang digunakan adalah lahan tanam, sludge biogas, biji sorgum dan biji jagung. Desain penelitian yang digunakan adalah rancangan acak lengkap pola faktorial 2 × 2 . Penelitian terdiri dari dua faktor perlakuan yaitu pengaruh tanaman (Faktor A) dan perbedaan jenis lahan (Faktor B). Faktor tanaman terdiri dari 2 taraf, yaitu tanaman sorgum dan jagung. Faktor perbedaan jenis lahan terdiri dari 2 taraf, yaitu lahan tanpa sludge biogas dan lahan dengan sludge biogas. Adapun perlakuan dalam penelitian ini, yaitu T1P0 : Sorgum yang ditanam di tanah tanpa sludge biogas, T1P1 : Sorgum yang ditanam di tanah dengan sludge biogas, T2P : Jagung yang ditanam di tanah tanpa sludge biogas, T2P1 : Jagung yang ditanam di tanah tanpa sludge biogas. Setiap jenis tanaman terdiri dari 96 tanaman yang dibagi menjadi dua, P0 : 48 tanaman dan P1 : 48, sehingga terdapat 192 satuan percobaan. Data yang diperoleh dianalisis variansi untuk mengetahui adanya perbedaan perlakuan terhadap peubah yang diamati berdasarkan uji $\mathrm{F}$ taraf $5 \%$ dan apabila terdapat perbedaan yang nyata dilanjutkan uji Duncan's Multiple Range Test (DMRT) taraf 5\%.
\end{abstract}

Kata kunci: Sludge, Sorgum, Jagung, Produksi tanaman

\section{Effect of Plant Media and Type of Plant to Nutrient Production of Aerial Part of Sorgum and Corn Plant}

\begin{abstract}
This research aims to know the biogas sludge utilization on planting media by looking at the difference in production of sorghum and maize crops. This research was conducted on November 2015 until January 2016 in the area around cultivation of Izzah Sejahtera Farm cattle farm, Jagoan Village, Sambi District, Boyolali District. The material used is planting land, sludge biogas, sorghum and corn seed. The research design used was a complete randomized design of $2 \times 2$ factorial pattern. The research consisted of two treatment factors namely plant effect (Factor A) and difference of land type (Factor B). Plant factor consists of 2 levels, namely sorghum and corn. Land type difference factor consists of 2 levels, ie land without sludge biogas and land with sludge biogas. The treatment in this study, namely T1P0: Sorgum grown on soil without sludge biogas, T1P1: Sorgum grown on soil with sludge biogas, T2P0: Corn grown on soil without sludge biogas, T2P1: Corn grown on soil without sludge biogas. Each plant consists of 96 plants divided into two, P0: 48 plants and P1: 48, so there are 192 units of experiment. The data obtained were analyzed by analysis of variance to know the difference of treatment to the observed variables based on $F$ test of $5 \%$ level and if there is a significant difference then continued to analyze with Duncan's Multiple Range Test (DMRT) $5 \%$.
\end{abstract}

Keywords: Sorghum, Sorghum seeds, Sludge biogas, Production

\section{PENDAHULUAN}

Limbah peternakan merupakan semua hasil dari buangan limbah peternakan yang bersifat padat, cair dan gas. Kotoran ternak sapi merupakan salah sstu limbah peternakan yang bisa mencemari lingkungan, hal ini dapat ditanggulangi dengan cara dimanfaatkan menjadi biogas serta mendukung konsep zero waste sehingga sistem pertanian yang berkelanjutan dan ramah lingkungan dapat dicapai. Hal ini sangat menguntungkan karena dapat mengoptimalkan sumber daya alam tanpa merusak alam, sehingga siklus ekologi tetap terjaga. Biogas merupakan renewable energi yang dapat dijadikan bahan bakar alternatif untuk menggantikan bahan bakar yang berasal dari fosil seperti minyak tanah dan gas alam. Biogas dapat di manfaatkan sebagai sumber energi alternatif

*Penulis Korespondensi: Budi Dwi Cahyono

Alamat: Jl. Ir. Sutami 36 A, Kentingan, Surakarta

E-mail: budi.dwi.c@gmail.com sehingga dapat mengurangi penggunaan kayu bakar, dengan demikian dapat mengurangi penebangan liar di hutan, dan tetap menjaga ekosistem hutan serta mengurangi efek rumah kaca karena biogas menghasilkan api biru yang bersih dan tidak menghasilkan asap.

Pengolahan kotoran sapi menjadi biogas dihasilkannya sisa yang berbentuk lumpur (sludge) yang dapat digunakan sebagai pupuk organik untuk tanaman. Sludge yang dihasilkan memiliki kadar pencemar biochemical oxygen demand (BOD) dan chemical oxygen demand (COD) berkurang sampai $90 \%$ sehingga pupuk dari limbah sudah tidak berbau, pupuk hasil dari pembentukan biogas berbentuk padat dan cair tersebut disebut sludge. Sludge berwujud cair cenderung padat, berwarna coklat terang atau hijau dan cenderung gelap, sedikit atau tidak mengeluarkan gelembung gas, tidak berbau dan tidak mengundang serangga, apabila sudah memadat dan mengering, warna sludge berubah menjadi coklat gelap bertekstur 
lengket, liat dan tidak mengkilat, bentuknya tidak seragam dan berkemampuan mengikat air yang baik. Sludge biogas mengadung 1,8-2,4\% nitrogen, 1,0$1,2 \%$ fosfor, $0,6-0,8 \%$ potassium dan $50-75 \%$ bahan organik, juga mengandung berbagai macam unsur yang dibutuhkan oleh tumbuhan seperti $\mathrm{P}$, magnesium $(\mathrm{Mg})$, kalsium $(\mathrm{Ca})$, kalium $(\mathrm{K})$, tembaga $(\mathrm{Cu})$ dan zink (Zn) Suzuki et al. (2001) cit. Oman (2003). Kandungan hara sludge berpontensi untuk dijadikan sebagai pupuk organik, dimana dapat menambah tingkat kesuburan tanah sehingga bisa meningkatkan kualitas hijauan dalam hal ini yaitu tanaman sorgum dan jagung.

Tanaman sorgum dan jagung memiliki banyak keunggulan. Sorgum dan jagung merupakan salah satu tanaman pangan penting, selain gandum dan padi. Sorgum dan jagung Selain untuk pangan dan pakan, jagung juga banyak digunakan industri makanan, minuman, kimia, dan farmasi. Berdasarkan komposisi kimia dan kandungan nutrisi, sorgum jagung mempunyai nilai tambah bagi usaha tani komoditas tersebut. Tanaman sorgum dan jagung memiliki daya adaptasi yang lebih tinggi terhadap iklim panas dan kering, dibandingkan dengan jenis tanaman pangan sumber karbohidrat lainnya. Tanaman ini dapat tumbuh dan berproduksi di daerah-daerah yang hanya memiliki curah hujan hanya $400 \mathrm{~mm} /$ th. Daerah yang subur dan curah hujannya lebih tinggi, produktivitasnya meningkat (Widowati 2011).

\section{MATERI DAN METODE}

\section{Tempat dan Waktu Penelitian}

Penelitian ini dilaksanakan dari bulan November 2015 sampai dengan Januari 2016 di lahan sekitar perkandangan peternakan sapi potong Izzah Sejahtera Farm di Desa Jagoan RT 03 RW 01, Kecamatan Sambi, Kabupaten Boyolali untuk pemeliharaan tanaman, sedangkan pada bulan Februari 2016 dilakukan uji analisis proximat di Laboratorium Ilmu Nutrisi Makanan Ternak, Program Studi Peternakan, Fakultas Pertanian, Universitas Sebelas Maret, Surakarta. Pengujian sampel tanah dan kandungan unsur hara sludge dilakukan di Laboratorium Kimia dan Kesuburan Tanah, Fakultas Pertanian, Universitas Sebelas Maret.

\section{Materi}

Alat yang digunakan untuk persiapan lahan adalah cangkul, gembor, meteran, pacak perlakuan, paranet, tali rafia, pisau, gunting, serta alat uji analisis proximat (vochdoss, penjepit, timbangan analitik, desikator, oven listrik, crusible, tanur, labu destruksi, kompor listrik, lemari asam, buret, erlenmeyer, gelas ukur dan pipet $5 \mathrm{ml}$ ).

Bahan yang digunakan menggunakan biji sorgum, biji jagung, tanah sludge, serta bahan uji analisis proximat (sampel tanaman sorgum, sampel taaman jagung, $\mathrm{NaOH}, \mathrm{H}_{2} \mathrm{SO}_{4}, \mathrm{HCl}$ dan indikator mix).

\section{Desain Penelitian}

Penelitian ini dilakukan secara eksperimental menggunakan rancangan acak lengkap pola faktorial dengan 2 perlakuan dan 12 ulangan sehingga terdapat 96 tanaman dengan masing-masing perlakuan, 48 tanaman di tanah sludge dan 48 tanaman di tanah tanpa sludge. Total ada 192 satuan percobaan. Perlakuan tersebut yaitu terdiri dari faktor pertama (P0 = Media tanah tanpa adanya limbah campuran sludge dan $\mathrm{P} 1$ = Media tanah dengan adanya limbah campuran sludge) dan faktor kedua (V1 = Penanaman tanaman jagung dan V2 = Penanaman tanaman sorgum).

\section{Persiapan Lahan}

Lahan yang akan ditanami dilakukan pengukuran luas yang akan digunakan dan membuat pagar mengelilingi lahan penelitian dengan cara memasang bambu dan paranet dengan bertujuan untuk membatasi bila ada hewan pengganggu. Lahan membujur dari barat ke timur dengan ukuran 9 × 5 meter. Tanah dengan kandungan sludge berada dibagian timur dengan ukuran 3,85 x 5 meter, dan tanah dengan tanpa adanya kandungan sludge berada di sebelah timur dengan ukuran 3,85 x 5 meter. Pembersihan lahan dari sisa tanaman sebelumnya dan gulma dilakukan menggunakan cangkul dan sabit.

\section{Pengambilan Sampel Tanah}

Sampel tanah di ambil 100 gram dengan cara acak di setiap media tanah yang berbeda. Terdapat 4 petak tanaman yang digunakan yaitu 2 petak tanah dengan adanya kandungan sludge (P1) dan 2 petak tanah tanpa adanya kandungan sludge (P0). Pengambilan sampel pertama pada 2 titik ditanah tanpa adanya kandungan sludge (P0) dan 2 titik di tanah dengan adanya kandungan sludge (P1). Jarak pengambilan sampel tanah dari satu titik ke titik yang lain minimal berjarak 1 meter. Analisis sampel dilakukan di Laboratorium Kimia dan KesuburanTanah, Fakultas Pertanian, Universitas Sebelas Maret. Hasil pengujian analisis kimia tanah ditunjukan pada Tabel 1 .

\section{Persiapan Media Tanam}

Persiapan media tanam dibuat 2 petak antar perlakuan dengan ukuran masing-masing petak dengan panjang 3,8 meter dan lebar 1,85 meter, serta jarak antar petak beda varietas 1,2 meter, sedangkan jarak antar beda jenis tanah $50 \mathrm{~cm}$. Lahan dibiarkan dan digemburkan selama 7-10 hari agar terjadi proses dekomposisi secara sempurna. Manfaat dari pengolahan tanah memberikan media tumbuh yang baik, sehingga tanaman dapat tumbuh dan memberikan hasil yang maksimal (Jumin, 1987). 
Tabel 1. Hasil analisis kimia tanah

\begin{tabular}{llccc}
\hline \hline No. & Analisis & Metode & P0 & P1 \\
\hline 1 & pH & - & 6,15 & 6,32 \\
2 & C. Organik (\%) & Walkey \& Black & 2,26 & 2,24 \\
3 & Bahan Organik (\%) & Walkey \& Black & 3,90 & 3,85 \\
4 & N total (\%) & Kjeldhal & 0,40 & 0,48 \\
5 & P (ppm) & Bray II & 11,69 & 14,39 \\
6 & K (me\%) & Penj. Amn Acetat pH 7 & 0,18 & 0,23 \\
\hline
\end{tabular}

Sumber: Laboratorium Kimia dan Kesuburan Tanah, FP, UNS (2015)

\section{Persiapan Penanaman}

Lahan yang sudah ditanami dilubangi untuk lubang tanam dengan kedalaman sekitar $5 \mathrm{~cm}$ dengan cara ditunggal, jarak tanam yang digunakan adalah 70 x $20 \mathrm{~cm}$, pembuatan lubang menggunakan alat bantu rafia untuk jarak $20 \mathrm{~cm}$ dan meteran dengan jarak 70 $\mathrm{cm}$. Setiap lubang tanam diisi dengan 3 biji.

\section{Penjarangan}

Penjarangan tanaman bertujuan untuk membuang tanaman-tanaman yang mati, terserang penyakit agar memberikan ruang pada tanaman yang hidup sehat agar dapat tumbuh dengan optimal.

\section{Pemanenan}

Pemanenan tanaman dilakukan pada tanaman berumur 99-112 hari (tanaman aereal). Pemotongan tanaman dilakukan dengan cara memotong tanaman 5 $\mathrm{cm}$ dari permukaan tanah. Penimbangan dilakukan setelah tanaman sudah selesai di potong guna mencari berat segar tanaman.

\section{Pengambilan Data}

Pengambilan data dilakukan di Laboratorium Ilmu Nutrisi Makanan Ternak dengan melakukan uji proximat untuk mencari kadar bahan kering (BK), lemak kasar (LK), serat kasar (SK), abu dan bahan ekstrak tanpa nitrogen (BETN). Pengambilan data dilakukan selama 2 minggu.

\section{Analisis Data}

Data hasil penelitian ini dianalisis menggunakan analisis variansi berdasarkan rancangan acak lengkap pola faktorial. Hasil yang berbeda nyata diuji lanjut dengan Duncan's Multiple Range Test (DMRT) untuk mengetahui perbedaan antar perlakuan (Yitnosumarto, 1993).

\section{HASIL DAN PEMBAHASAN}

\section{Produksi Bahan Kering}

Produksi BK bagian aerial tanaman sorgum dan jagung yang ditanam pada media tanam yang berbeda disajikan pada Tabel 2.

Produksi BK tanaman sorgum dan jagung yang ditanam pada media tanam lahan tanpa sludge dengan lahan sludge yaitu 1,849 ton/ha dan 2,099 ton/ha. Hasil analisi variansi menunjukkan bahwa penanaman pada media tanam yang berbeda berpengaruh tidak nyata terhadap produksi bahan kering tanaman sorgum dan jagung. Hasil tersebut diduga dipengaruhi oleh unsur hara yang terkandung dalam lahan tersebut, dikarenakan unsur hara $\mathrm{N}$ yang terkandung dalam $\mathrm{P} 0$ yang rendah sehingga perlu dilakukan pemupukan sehingga memenuhi kebutuhan hara tanaman sorgum dan jagung sehingga pada lahan P1 hasilnya lebih besar karena kandungan unsur hara memiliki jumlah yang cukup dengan kebutuhan dan perkembangan sorgum dan jagung. (Ginting, 2017) menyatakan bahwa setiap tanaman, hara yang diberikan akan mempengaruhi besar kecilnya kandungan nutrisi dalam tanaman tersebut.

Produksi BK tanaman sorgum dan jagung yang ditanam pada media tanam lahan tanpa sludge dengan lahan sludge yaitu 1,698 ton/ha dan 2,179 ton/ha. Hasil analisis variansi menunjukkan bahwa perbedaan jenis tanaman berpengaruh nyata $(\mathrm{P}<0,05)$ terhadap produksi BK (Tabel 2). Produksi tanaman jagung lebih tinggi dari tanaman sorgum, hal ini dikarenakan perbedaan bobot segar tanaman jagung lebih banyak dari tanaman sorgum, dilihat dari morfologi tanaman jagung yang lebih unggul dari tanaman sorgum dari segi jumlah daun, panjang daun dan tinggi tanaman. Tanaman jagung mempuyai jumlah daun yang berbeda-beda, yaitu antara 8 sampai 48 dengan ratarata 12-18 helai daun setiap tanaman (Effendi dan Sulistiati, 1991).

Produksi BK tanaman sorgum dan jagung pada lahan tanpa sludge yaitu 1,698 ton/ha dan 2,179 ton/ha serta produksi BK tanaman sorgum dan jagung pada lahan sludge berturut-turut yaitu 1,787 ton/ha dan 2,270 ton/ha. Hasil analisis variansi menunjukkan bahwa interaksi pada tanaman sorgum dan jagung yang ditanam pada media tanam yang berbeda berpengaruh tidak nyata terhadap produksi bahan kering tanaman sorgum dan jagung. Hal ini diduga

Tabel 2. Produksi bahan kering tanaman sorgum dan jagung yang ditanam pada tanah yang berbeda (ton/ha)

\begin{tabular}{|c|c|c|c|}
\hline \multirow{2}{*}{ Lahan } & \multicolumn{2}{|c|}{ Tanaman } & \multirow{2}{*}{ Rerata } \\
\hline & $\mathrm{T} 1$ & $\mathrm{~T} 2$ & \\
\hline P0 & 1,609 & 2,088 & 1,849 \\
\hline $\mathrm{P} 1$ & 1,787 & 2,270 & 2,099 \\
\hline Rerata & $1,698^{b}$ & $2,179^{\mathrm{a}}$ & \\
\hline
\end{tabular}


Tabel 3. Produksi lemak kasar tanaman dan jagung yang ditanam pada tanah yang berbeda (ton/ha)

\begin{tabular}{cccc}
\hline \hline \multirow{2}{*}{ Lahan } & \multicolumn{2}{c}{ Tanaman } & \multirow{2}{*}{ Rerata } \\
\cline { 2 - 3 } & T1 & T2 & 0,017 \\
P0 & 0,013 & 0,020 & 0,021 \\
\hline R1 & 0,014 & 0,027 &
\end{tabular}

Keterangan: ${ }^{\mathrm{a}, \mathrm{b}}$ superskrip yang berbeda pada baris yang sama menunjukkan perbedaan yang sama menunjukkan perbedaan sangat nyata $(\mathrm{P}<$ $0,01)$.

karena tanah tanpa sludge dan dengan sludge belum memberikan asupan hara yang maksimal, sehinnga penyerapan hara tanaman belum terserap maksimal sehingga tidak ada interaksi pada tanaman sorgum dan jagung. Hal ini juga mengindikasikan bahwa tanah yang digunakan memiliki tingkat kesuburan yang sedang. Berdasarkan hasil analisis kimia tanah yang disajikan pada Tabel 1, tanah pada lokasi penelitian memiliki pH P0 6,15 dan P1 6,32. (Sarief, 1989) menyatakan bahwa tanah yang memiliki $\mathrm{pH}$ tanah antara 5,5 sampai 7,5 (mendekati netral) mengandung unsur hara dalam jumlah cukup banyak di dalam tanah. (Seputro, 1994) menyatakan tanaman akan tumbuh dengan baik dan subur apabila unsur hara yang dibutuhkan tanaman tersedia dalam jumlah yang cukup.

\section{Produksi Lemak Kasar}

Produksi LK bagian aerial tanaman sorgum dan jagung yang ditanam pada media tanah yang berbeda disajikan pada Tabel 3. Produksi lemak kasar tanaman sorgum dan jagung yang ditanam pada lahan tanpa sludge dan lahan sludge yaitu 0,017 ton/ha dan 0,021 ton/ha. Hasil analisi variansi menunjukkan bahwa penanaman pada media tanam yang berbeda berpengaruh tidak nyata terhadap produksi lemak kasar tanaman sorgum dan jagung. Hasil tersebut diduga dipengaruhi oleh unsur hara yang terkandung dalam lahan tersebut, dikarenakan unsur hara $\mathrm{N}$ yang terkandung dalam P0 yang rendah sehingga perlu dilakukan pemupukan sehingga memenuhi kebutuhan hara tanaman sorgum dan jagung sehingga pada lahan P1 hasilnya lebih besar karena kandungan unsur hara memiliki jumlah yang cukup dengan kebutuhan dan perkembangan sorgum dan jagung. (Meilany, 2010) menyatakan kandungan lemak kasar dipengaruhi oleh unsur hara $\mathrm{N}$ dari media tanam, dimana semakin banyak unsur hara yang tersedia maka akan mempengaruhi kandungan nutrien yang diserap oleh tanaman.

Produksi lemak kasar tanaman sorgum dan jagung yaitu 0,014 ton/ha dan 0,023 ton/ha. Hasil analisis variansi menunjukkan bahwa perbedaan jenis tanaman berpengaruh sangat nyata $(\mathrm{P}<0,01)$ terhadap produksi LK (Tabel 3). Produksi LK tanaman jagung lebih tinggi dari tanaman sorgum, hal ini mengidikasikan bahwa pemberian tambahan unsur hara belum dapat memberikan hasil positif terhadap pertumbuhan dan kandungan nutrien tanaman sorgum. Produksi lemak kasar sangat dipengaruhi oleh unsur hara pada tanah. Data yang dihasilkan menunjukan P0 tergolong dalam sedang, dan dari data P1 menghasilkan data yang tidak berbeda nyata hal ini mengindikasikan sludge yang merendam pada lahan P1 kurang baik. (Meilany, 2010) menyatakan kandungan lemak kasar dipengaruhi oleh unsur hara $\mathrm{N}, \mathrm{P}, \mathrm{K}$ dari media tanam, dimana semakin banyak unsur hara yang tersedia maka akan mempengaruhi kandungan nutrien yang diserap oleh tanaman.

Produksi LK tanaman sorgum dan jagung pada lahan tanpa sludge yaitu 0,013 ton/ha dan 0,020 ton/ha serta produksi LK tanaman sorgum dan jagung pada lahan sludge berturut-turut yaitu 0,014 dan 0,027. Hasil analisis variansi menunjukkan bahwa interaksi pada tanaman sorgum dan jagung yang ditanam pada media tanam yang berbeda berpengaruh tidak nyata terhadap produksi lemak kasar tanaman sorgum dan jagung. Hal ini diduga karena tanah tanpa sludge dan dengan sludge belum memberikan asupan hara yang maksimal, sehinnga penyerapan hara tanaman belum terserap maksimal sehingga tidak ada interaksi pada tanaman sorgum dan jagung. Hal ini juga mengindikasikan bahwa tanah yang digunakan memiliki tingkat kesuburan yang sedang. Berdasarkan hasil analisis kimia tanah yang disajikan pada Tabel 1 , tanah pada lokasi penelitian memiliki pH P0 6,15 dan P1 6,32. (Sarief, 1989) menyatakan bahwa tanah yang memiliki $\mathrm{pH}$ tanah antara 5,5 sampai 7,5 (mendekati netral) mengandung unsur hara dalam jumlah cukup banyak di dalam tanah. (Seputro, 1994) menyatakan tanaman akan tumbuh dengan baik dan subur apabila unsur hara yang dibutuhkan tanaman tersedia dalam jumlah yang cukup.

\section{Produksi Serat Kasar}

Produksi SK bagian aerial tanaman Sorgum dan jagung yang ditanam pada media tanah yang berbeda disajikan pada Tabel 4. Produksi serat kasar tanaman sorgum dan jagung yang di tanam pada lahan tanpa sludge dan lahan dengan sludge yaitu 0,770 dan 0,619. Hasil analisi variansi menunjukkan bahwa media tanam berpengaruh tidak nyata terhadap produksi serat kasar tanaman sorgum dan jagung. Hasil tersebut diduga dipengaruhi oleh unsur hara yang terkandung dalam lahan tersebut, menurut (Hardjowigeno, 2003) bahwa kriteria sifat kimia tanah dengan kriteria sedang yaitu memiliki kadar $\mathrm{N}$ total antara 0,21 - 0,50. Kandungan $\mathrm{N}$ dalam tanah yang digunakan $0,40-$ 0,48 , dikarenakan unsur hara $\mathrm{N}$ yang terkandung dalam P0 dan P1 tergolong sedang dan mampu untuk memenuhi asupan unsur hara tanaman sorgum dan jagung, sehingga tidak terdapat pengaruh yang nyata pada tanaman sorgum dan jagung pada lahan P0 dan P1. Meilany (2010) menyatakan kandungan lemak 
Tabel 4. Produksi serat kasar tanaman dan jagung yang ditanam pada tanah yang berbeda (ton/ha)

\begin{tabular}{|c|c|c|c|}
\hline \multirow{2}{*}{ Lahan } & \multicolumn{2}{|c|}{ Tanaman } & \multirow{2}{*}{ Total } \\
\hline & T1 & $\mathrm{T} 2$ & \\
\hline P0 & 0,607 & 0,932 & 0,770 \\
\hline $\mathrm{P} 1$ & 0,554 & 0,085 & 0,619 \\
\hline Total & $0,581^{b}$ & $0,809^{\mathrm{a}}$ & \\
\hline
\end{tabular}

Keterangan: ${ }^{\mathrm{a}, \mathrm{b}}$ superskrip yang berbeda pada baris yang sama menunjukkan hasil non sicnifican.

kasar dipengaruhi oleh unsur hara $\mathrm{N}$ dari media tanam, dimana semakin banyak unsur hara yang tersedia maka akan mempengaruhi kandungan nutrien yang diserap oleh tanaman.

Produksi serat kasar tanaman sorgum dan jagung yaitu 0,581 ton/ha dan 0,809 ton/ha. Hasil analisis variansi menunjukkan bahwa perbedaan jenis tanaman berpengaruh tidak nyata terhadap produksi SK (Tabel 4). Hal ini juga mengindikasikan bahwa tanah yang digunakan memiliki tingkat kesuburan yang sedang. Berdasarkan hasil analisis kimia tanah yang disajikan pada Tabel 1, tanah pada lokasi penelitian memiliki pH P0 6,15 dan P1 6,32. (Sarief, 1989) menyatakan bahwa tanah yang memiliki $\mathrm{pH}$ tanah antara 5,5 sampai 7,5 (mendekati netral) mengandung unsur hara dalam jumlah cukup banyak di dalam tanah. (Seputro, 1994) menyatakan tanaman akan tumbuh dengan baik dan subur apabila unsur hara yang dibutuhkan tanaman tersedia dalam jumlah yang cukup. Berdasarkan analisis kimia tanah yang disajikan pada tabel 1, tanah pada lokasi penelitian memiliki pH 5,62. (Sarief, 1989) menyatakan bahwa tanah yang memiliki $\mathrm{pH}$ tanah antara 5,5 sampai 7,5 (mendekati netral) mengandung unsur hara dalam jumlah cukup banyak didalam tanah.

Produksi SK tanaman sorgum dan jagung pada lahan tanpa sludge yaitu 0,607 ton/ha dan 0,932 ton/ha serta produksi SK tanaman sorgum dan jagung pada lahan dengan sludge berturut-turut yaitu 0,554 ton/ha dan 0,685 ton/ha. Hasil ini menunjukan bahwa kandungan serat kasar tanaman jagung dan sorgum tidak dipengaruhi oleh adanya sludge di dalam media tanamnya. Menurut Meilany (2010) tidak berpengaruhnya perlakuan sumber unsur hara terhadap kandungan serat menunjukkan bahwa kandungan unsur hara pada masing-masing perlakuan dan media tanam sudah cukup untuk memenuhi kebutuhan tanaman dari awal pertumbuhan untuk membentuk kandungan serat pada tanaman sorgum dan jagung. Serat kasar terdiri dari selullosa, hemiselullosa dan lignin. Hasil analisis variansi menunjukan tidak adanya interaksi antara tanah sludge dengan tanah tanpa sludge terhadap produksi serat kasar (SK) tanaman jagung dan sorgum (Tabel 4). Hasil tersebut sejalan dengan penelitian (Widyati et al., 2008) yang menyatakan bahwa pemupukan $\mathrm{P}$ sampai $100 \mathrm{~kg}$ $\mathrm{P}_{2} \mathrm{O}_{5} /$ ha tidak mempengaruhi produksi serat kasar alfalfa.

\section{Produksi Bahan Ekstrak Tanpa Nitrogen}

Produksi BETN bagian aerial tanaman Sorgum dan jagung yang ditanam pada media tanah yang berbeda disajikan pada Tabel 5 .

Produksi BETN tanaman sorgum dan jagung yang di tanam pada lahan tanpa sludge dan lahan dengan sludge yaitu 0,909 ton/ha dan 1,085 ton/ha. Hasil analisis variansi menunjukkan bahwa penanaman pada media tanam yang berbeda berpengaruh tidak nyata terhadap produksi BETN tanaman sorgum dan jagung. Hasil tersebut diduga dipengaruhi oleh unsur hara yang terkandung dalam lahan tersebut rendah, dikarenakan unsur hara $\mathrm{N}$ yang terkandung dalam P0 dan P1 tergolong sedang sehingga tidak berpengaruh nyata terhadap produksi BETN tanaman sorgum dan jagung. Menurut (Hardjowigeno, 2003) bahwa kriteria sifat kimia tanah dengan kriteria sedang yaitu memiliki kadar $\mathrm{N}$ total antara $0,21-0,50$. Kandungan $\mathrm{N}$ dalam tanah yang digunakan $\mathrm{P} 0$ dan $\mathrm{P} 1$ masing - masing yaitu $0,40-$ 0,48 .

Produksi BETN tanaman sorgum dan jagung yang di tanam pada lahan tanpa sludge dan lahan dengan sludge yaitu 0,913 ton/ha dan 1,082 ton/ha. Hasil analisis variansi menunjukkan perbedaan jenis tanaman berpengaruh sangat nyata $(\mathrm{P}<0,01)$ terhadap produksi BETN tanaman sorgum dan jagung. Produksi BETN tanaman jagung lebih tinggi dari tanaman sorgum, hal ini mengidikasikan bahwa pemberian tambahan unsur hara belum dapat memberikan hasil positif terhadap pertumbuhan dan kandungan nutrien tanaman sorgum. Menurut Nurdin et al. (2008) bahwa penyerapan unsur hara $\mathrm{N}, \mathrm{P}, \mathrm{K}$ yang baik akan memengaruhi kandungan nutrien tanaman, semakin baik tanaman menyerap unsur hara akan semakin baik kandungan nutriennya.

Hasil analisis menunjukan bahwa tidak terdapat interaksi pada tanah tanpa sludge dan lahan dengan sludge $(\mathrm{P}>0,05)$. BETN sangat dipengaruhi oleh

Tabel 5. Produksi Bahan Ekstrak Tana Nitrogen tanaman dan jagung yang ditanam pada tanah yang berbeda (ton/ha)

\begin{tabular}{|c|c|c|c|}
\hline \multirow{2}{*}{ Lahan } & \multicolumn{2}{|c|}{ Tanaman } & \multirow{2}{*}{ Total } \\
\hline & T1 & T2 & \\
\hline$\overline{\mathrm{P} 0}$ & 0,878 & 0,941 & 0,909 \\
\hline P1 & 0,948 & 1,223 & 1,085 \\
\hline Total & $0,913^{b}$ & $1,082^{\mathrm{a}}$ & \\
\hline
\end{tabular}


kandungan nutrien tanaman sorgum dan jagung yang lain dimana BETN diperoleh dari perhitungan $\mathrm{BETN}=100 \%$ - (\%kadar air + abu + protein kasar + $\%$ lemak kasar + serat kasar (Hading, 2014). Alanisis lahan juga menunjukan bahwa produksi BETN berpengaruh tidak nyata pada lahan $\mathrm{P} 0$ dan $\mathrm{P} 1$.

\section{SIMPULAN}

Hasil penelitian dapat disimpulkan bahwa media tanam (lahan mengandung sludge) tidak memberikan pengaruh terhadap produksi BK, LK, SK, BETN pada masing - masing tanaman (sorgum dan jagung), tetapi tanaman jagung memiliki produksi nutrien lebih tinggi dibandingkan dengan tanaman sorgum. Tidak ada interaksi antara media tanam yang mengandung sludge dengan jenis tanaman terhadap produksi nutrien bagian aerial tanaman sorgum dan jagung.

\section{DAFTAR PUSTAKA}

Effendi, S dan N. Sulistiati. 1991. Bercocok Tanam Jagung. Yasaguna. Bogor.

Hardjowigeno, S. 2003. Ilmu Tanah Ultisol. Edisi Baru. Akademika Pressindo. Jakarta.

Ginting, A.K. 2017. Pengaruh Pemberian Nitrogen Dan Fosfor Terhadap Pertumbuhan Legum Calopogonium mucunoides, Centrosema pubescens dan Arachis pintoi. Skripsi. Universitas Jambi. Jambi.

Hading, R. H. 2014. Kandungan Protein Kasar, Lemak Kasar, Serat Kasar dan BETN Silase Pakan Lengkap Berbahan Dasar Rumput Gajah dan Biomassa Murbei. Skripsi. Fakultas Peternakan Universitas Hasanuddin. Makassar.

Jumin, HS. 1987. Ekologi Tanaman Suatu Pendekatan Fisiologis. Rajawali Press. Jakarta.

Meilany, R. 2010. Analisis Produksi dan Kandungan Zat Makanan Hijauan Jagung (Zea Mays L.) Umur 15 Hari yang Ditanam pada Media Tanah dan Arang Sekam dengan Pemberian Pupuk NPK dan Pupuk Lengkap (Makro dan Mikro). Skripsi. Institut Pertanian Bogor. Bogor.

Nurdin, Maspeke, P., Ilahude, Z. dan Zakaria. 2008. Pertumbuhan dan Hasil Jagung yang Dipupuk N, $\mathrm{P}$ dan $\mathrm{K}$ pada Tanah Vertisol Isimu Utara Kabupaten Gorontalo. Jurnal Tanah Tropika 14(1): 49-56.

Oman. 2003. Kandungan Nitrogen (N) Pupuk Organik Cair dari Hasil Penambahan Urine pada Limbah (Sludge) Keluaran Instalasi Gas Bio dengan Masukan Feces Sapi. Skripsi. Jurusan Ilmu Produksi Ternak. Institut Pertanian Bogor. Bogor.

Sarief, S. 1989. Kesuburan dan Pemupukan Tanah Pertanian. Pustaka Buana. Bandung.

Seputro, D.D. 1994. Pengantar Fisiologi Tumbuhan. Gramedia Pustaka Utama. Jakarta.

Widowati, S. 2011. Sorgum: Penanganan dan Pengolahan Berbagai Produk Pangan. Balai
Besar Penelitian dan Pengembangan Pascapanen Pertanian. Bogor.

Widyati, E. 2008. Peranan Mikroba Tanah pada Kegiatan Rehabilitasi Lahan Bekas Tambang. Info Hutan 5(2): 151-160.

Yitnosumarto, S. 1993. Percobaan: Perancangan, Analisis dan Interpretasinya. Gramedia. Jakarta. 